\title{
Entre sussurros e silêncios: o jogo da linguagem em The Handmaid's Tale
}

\section{Resumo}

O presente artigo tem como objetivo analisar a importância da linguagem nas disputas de poder travadas no universo do romance The Handmaid's Tale (1985), de Margaret Atwood. Considerando o caráter crítico da narrativa distópica, pretende-se demonstrar, a partir de teóricos como Bakhtin (2009) e Foucault $(2003,2014)$, como as estratégias de controle do discurso empregadas pelos governantes de Gilead, assim como os atos de resistência empreendidos pela protagonista por meio da linguagem, refletem as próprias relações de poder existentes.

Palavras-chave: The Handmaid's Tale. Distopias. Linguagem e cultura. Poder (Filosofia).

\author{
Juliene Kely Zanardi \\ Doutoranda em Letras pela \\ Universidade do Estado do Rio de \\ Janeiro - UERJ. \\ Brasil \\ julienezanardi@gmail.com
}

\section{Para citar este artigo:}

ZANARDI, Juliene Kely. Entre sussurros e silêncios: o jogo da linguagem em The Handmaid's Tale.

PerCursos, Florianópolis, v. 21, n.47, p. 57 - 78, set./dez. 2020.

DOI: $10.5965 / 1984724621472020057$

http://dx.doi.org/10.5965/1984724621472020057 


\title{
Between whispers and silences: the play with language in The Handmaid's
}

\section{Tale}

\begin{abstract}
The present article aims to analyze the importance of language in power disputes in the universe of the novel The Handmaid's Tale (1985), by Margaret Atwood. Considering the critical character of the dystopian narrative, it is intended to demonstrate, from theorists such as Bakhtin (2009) and Foucault (2003, 2014), how the speech control strategies employed by Gilead's rulers, as well as the acts of resistance undertaken by the protagonist through language, reflect the existing power relations.
\end{abstract}

Keywords: The Handmaid's Tale. Dystopias. Language and Culture. Power (Philosophy). 


\section{Linguagem e poder nas distopias}

A distopia como gênero literário teve início na metade final do século XVIII, associada ao crescente processo de mecanização e exploração que deu lugar à promessa de progresso social oriunda da Revolução Industrial (SISK, 1997, p. 6). Atreladas a esse contexto, as distopias surgem como uma forma de problematizar tendências sociais em curso por meio de uma extrapolação que evidencie possíveis reveses decorrentes de sua concretização, ainda que as sociedades representadas possam parecer a princípio convidativas, a depender da perspectiva. Em Brave New World, de Aldous Huxley (2009), por exemplo, as personagens, em geral, se mostram satisfeitas por terem sido condicionadas a aceitar seus papéis, apesar da rígida estratificação e falta de mobilidade social.

Embora seja concebida como ficção, a distopia aponta para o que existe fora dela, criticando o mundo do leitor por meio de um deslocamento. A partir de uma projeção pessimista da realidade, as narrativas distópicas mostram que o progresso social e o avanço tecnológico nem sempre culminam em benefícios para a humanidade (ABREU, 2012, p. 18). Como explica Sisk (1997, p. 6-7), as distopias têm a finalidade didática de alertar ao leitor um mal porvir e sugerir ações a fim de impedi-lo. Para isso, o escritor apresenta em sua narrativa aquilo que considera a consequência negativa lógica das tendências observáveis na sociedade em que vive. Não se trata, todavia, de simplesmente aterrorizar o leitor por meio de uma visão catastrófica do futuro, mas, sobretudo, de motivá-lo a lidar com problemas do presente a fim de revertê-los (SISK, 1997, p. 11).

Conforme sinaliza Trujillo (2016, p. 188), o universo apresentado nas distopias é concebido a partir da contraposição de duas narrativas: a do regime hegemônico e a da resistência a ele. A linguagem apresenta-se como um elemento importante na construção de tal oposição. Segundo a autora, o contraste entre uso social e antissocial da linguagem (o que pode ou não ser dito) a torna o principal meio de repressão e de resistência nas distopias. De maneira similar, Sisk (1997, p. 2) afirma que as distopias de língua inglesa do século XX demonstram uma especial ênfase na linguagem como arma fundamental de resistência à opressão, além de evidenciar o desejo correspondente por parte das estruturas dominantes de controlá-la como forma de coibir a dissidência. 
A título de exemplo, pode-se mencionar a importância da linguagem em 1984, de George Orwell (2009). Na obra, que é considerada um dos clássicos da ficção distópica, um dos instrumentos repressivos utilizados pelo governo autoritário que controla a sociedade apresentada na narrativa é a criação do newspeak (traduzido para o português como "novilíngua”). Trata-se do desenvolvimento de um novo idioma para uso da população, baseado na condensação ou na remoção de palavras, restringindo, assim, a capacidade de elaborar e transmitir pensamentos. Em outros termos, por meio do controle do vocabulário, impede-se que ideias indesejáveis tomem forma.

O protagonista Winston Smith representa, no romance, o principal contraponto ao regime. Como funcionário do governo, seu trabalho consiste em alterar registros históricos para que estejam de acordo com a versão do passado que o Partido Oficial deseja apresentar, o que configura mais uma forma de controle pela linguagem por meio da manipulação do discurso. A oposição de Winston ao regime opressor se inicia com a aquisição de um diário (feita de forma clandestina), no qual ele começa a registrar suas experiências e pensamentos, o que por si só já é um ato de transgressão. Já no primeiro capítulo da obra, a personagem contempla o diário e se depara com uma frase escrita repetidamente por ele próprio em letras garrafais: "DOWN WITH BIG BROTHER", em português, “ABAIXO AO GRANDE IRMÃO”, figura que representa o governo totalitário a que está submetido. Assim, se, por um lado, a linguagem é o principal mecanismo de controle do governo autoritário apresentado em 1984, por outro, é também por meio dela que Winston se percebe e se constrói, ao longo da narrativa, como um opositor a ele.

Em verdade, esse embate de forças que atravessa a linguagem não configura uma mera estratégia literária, mas representa as próprias disputas de poder existentes. Como assevera Bakhtin (2009, p. 126), toda "palavra é ideológica e toda utilização da língua está ligada à evolução ideológica". Consoante a visão do filósofo, a enunciação não é simples fruto de um ato individual. Todo discurso é perpassado por várias vozes, uma vez que este é sempre motivado ou influenciado por outros discursos, respondendo a eles, refutando-os, confirmando-os, antecipando respostas ou potenciais objeções etc. Assim, na palavra, como signo ideológico que é, confrontam-se índices de valor contraditórios, 
servindo ela como uma espécie de arena para a luta entre classes. Como atenta Bakhtin (2009, p. 48), cabe notar, entretanto, um movimento de monologização do discurso que as estruturas hegemônicas ambicionam impor como verdade: "A classe dominante tende a conferir ao signo ideológico um caráter intangível e acima das diferenças de classe, a fim de abafar ou de ocultar a luta dos índices sociais de valor que aí se trava, a fim de tornar o signo monovalente".

De maneira semelhante, Foucault (2003) observa que, em toda sociedade, a produção do discurso é controlada, selecionada, organizada e redistribuída por certo número de procedimentos que têm por finalidade conjurar seus poderes e perigos, controlar seu acontecimento aleatório e determinar os sujeitos que falam. Isso porque o discurso "não é simplesmente aquilo que traduz as lutas e os sistemas de dominação, mas aquilo por que, pelo que se luta, o poder do qual nos queremos apoderar" (Foucault, 2003, p. 10). Assim, as relações de poder - sua manutenção ou mudança - passam pela questão da linguagem.

A partir do exposto, o objetivo do presente artigo é analisar a obra The Handmaid's Tale, de Margaret Atwood (2017), observando a importância da linguagem nas disputas de poder entre as personagens no interior da narrativa. Tendo em vista tal finalidade, a próxima seção será dedicada a uma breve contextualização do universo distópico apresentado no romance, evidenciando os mecanismos empregados pelas estruturas dominantes para a manutenção do poder.

\section{A teocracia de Gilead: o regime opressor de THT}

O romance The Handmaid's Tale (traduzido no Brasil como O conto da Aia), de Margaret Atwood, foi publicado pela primeira vez em 1985. Como constata Abreu (2012, p. 10-11), a obra reflete, de modo explícito, o movimento antifeminista que se estabeleceu nos Estados Unidos durante a década de 80. Nesse período, o New Right, corrente conservadora guiada por líderes religiosos, declarou as seguidoras do feminismo como inimigas, apontando-as como as responsáveis pela degradação da família. Partindo de crenças puritanas implantadas no solo americano no século XVII, os adeptos do New Right pregavam, entre outras pautas, a submissão da mulher ao marido e condenavam sua 
inserção no mercado de trabalho. Ainda nesse contexto, membros da vertente conhecida como Christian Right investiram em estações televisivas como veículo de difusão e popularização de seus ideais, fazendo com que estes ganhassem cada vez mais força e influência no Congresso Americano.

Remetendo a esse cenário, as classes dominantes que regem a sociedade distópica descrita em The Handmaid's Tale comungam dos pressupostos do New Right. Após uma crise ambiental que, entre outras consequências, fez aumentar os índices de infertilidade entre a população, os idealizadores de Gilead - país fictício que corresponde a uma parte do atual território dos EUA - dissolvem as instituições democráticas e instituem um governo autoritário que tem como diretriz a narrativa bíblica. A história é contada do ponto de vista de Offred, que exerce nessa sociedade a função de Aia, papel designado a mulheres férteis que devem gerar filhos para os casais da elite que não conseguem concebê-los. Em seu relato, Offred não apenas descreve sua percepção sobre o meio em que vive como também relembra sua vida pregressa e o processo de formação de Gilead.

Uma das transformações sociais registradas em suas memórias é justamente a gradativa perda de direitos das mulheres, que, no início da transição, passaram a ser proibidas de administrar e, posteriormente, até mesmo de obter sua própria renda, ficando subordinadas à tutela dos maridos ou dos parentes mais próximos do sexo masculino. No momento em que se passa a narrativa, a situação é ainda pior. Qualquer pessoa em desacordo com a doutrina prescrita não está apta a fazer parte da sociedade de Gilead. Offred, por ter constituído uma família com um homem casado no período préregime, seria considerada indigna. Sua capacidade de ter filhos, no entanto, a torna um bem desejável, fazendo com que sua vida seja poupada.

Retomando o método do corpo supliciado, comum no Ocidente até o século XVII (FOUCAULT, 2014), não só a tortura e a morte, mas também a sua exibição, configuram uma das estratégias empregadas pelo governo de Gilead para controlar e punir o comportamento considerado desviante. Depois de execuções públicas cruéis e aviltantes, chamadas de "Salvamentos", os corpos dos hereges são expostos no Muro com placas que simbolizam seus delitos. Como a própria narrativa de Offred revela, a punição 
transformada em espetáculo tem um objetivo óbvio: os corpos estão ali expostos para serem vistos e servirem de exemplo para aqueles que intentam se rebelar contra o sistema.

Além do uso da força física, a violência simbólica, em suas diferentes manifestações, também configura um importante meio de controle social. A sociedade de Gilead se organiza em torno de um rígido sistema de castas que, inspirado em passagens bíblicas, delimita os papéis sociais a serem desempenhados por seus habitantes. No topo da cadeia, encontram-se os Comandantes, homens da elite que governam o país. Os Anjos (o exército de Gilead), os Guardiões (vigilantes/serviçais domésticos) e os Olhos (espécie de polícia secreta) são outras funções desempenhadas pelos homens nessa sociedade.

No que tange aos papéis femininos, as Esposas (mulheres dos Comandantes) e as Tias (preceptoras das Aias) ocupam o topo da hierarquia. As Marthas são as responsáveis pelas tarefas domésticas. Na base da pirâmide social, encontram-se as Aias, mulheres pecadoras, porém férteis, a quem é oferecida a possibilidade de redenção, caso sejam capazes de gerar filhos para as famílias das elites. Nas classes mais populares, há ainda as Econoesposas, mulheres oriundas de famílias humildes que são dadas em casamento aos homens das castas inferiores e acumulam as funções de esposa, mãe e empregada.

Além do rótulo dado a cada uma delas, a distinção entre as castas também é marcada por sua indumentária. Assim, os Comandantes usam trajes pretos. As Esposas se vestem de azul; as Tias, de marrom; as Marthas, de verde. Às Aias, são destinadas vestimentas vermelhas e, como acessório, cones brancos que cobrem seus rostos. Simbolizando o acúmulo de funções, as Econoesposas usam roupas com listras de três cores: azul, verde e vermelho.

Cabe ressaltar que tais escolhas não são aleatórias. Ao contrário, fazem parte das estratégias simbólicas de controle social. A esse respeito, é interessante destacar as observações feitas pela própria autora em um ensaio publicado no The New York Times:

A indumentária utilizada pelas mulheres de Gilead é inspirada na iconografia religiosa ocidental - as Esposas vestem azul de pureza, 
remetendo à Virgem Maria; as Aias usam vermelho, do sangue do parto, mas também de Maria Madalena. Além disso, a cor vermelha é mais fácil de notar se alguém está fugindo. As esposas dos homens das classes inferiores, chamadas de Econoesposas, vestem listras. Eu devo confessar que os cones que ocultam a face não foram inspirados apenas na indumentária vitoriana ou nos hábitos das freiras, mas também no rótulo de Old Dutch Cleanser [um produto de limpeza dos anos 40], que mostrava uma mulher com a face coberta, e que me assustava quando eu era criança. Muitos regimes totalitários usavam a vestimenta, proibida ou imposta, como forma de identificar e controlar pessoas - pense nas estrelas amarelas ou no roxo dos romanos - e, muitas vezes, isso teve como base premissas religiosas. Assim é mais fácil fazer com que as pessoas sejam vistas como hereges. (ATWOOD, 2017b, tradução nossa)

Assim, a cor da roupa simboliza o prestígio ou o estigma destinado a cada casta dentro da sociedade de Gilead. Mais do que isso, a padronização do vestuário visa ao assujeitamento de seus habitantes, negando-lhes a possibilidade de se verem como indivíduos. Obliterada por sua vestimenta, Offred se sente "duplicada” ao lado da Aia que Ihe acompanha nas compras e, em seu relato, deixa transparecer como o traje que veste contribui para a negação de sua subjetividade:

Tudo, exceto a touca de grandes abas na minha cabeça, é vermelho: da cor do sangue, que nos define. A saia desce à altura de meus tornozelos, rodada, franzida e presa a um corpete de peitilho liso que se estende sobre os seios, as mangas são bem largas e franzidas. As toucas também seguem o modelo padronizado; são destinadas a nos impedir de ver e também de sermos vistas. Nunca fiquei bem de vermelho, não é a minha cor. (ATWOOD, 2017a, p. 16)

É por meio da linguagem, todavia, que esse apagamento se dá de forma mais severa. Para além da roupa que veste, ser rotulada como "Aia" determina toda a existência de Offred no regime teocrático em que vive. Embora todos os habitantes de Gilead tenham sua subjetividade podada em algum nível, pertencer a essa casta torna maior o seu grau de assujeitamento. Como outras mulheres de sua classe, ela não tem direito ao seu próprio nome, o qual permanece desconhecido ao longo da narrativa. Offred é o nome que lhe foi imposto pelo regime, formado pela junção do primeiro nome de seu Comandante, Fred, ao prefixo "of" que significa "pertencente a", o que a descaracteriza como uma pessoa e a transforma em propriedade de alguém. Como 
esclarece a própria autora, há ainda uma segunda possibilidade de interpretação: a similaridade com a palavra "offered" ("ofertada”, em português) simboliza sua condição de oferenda religiosa ou de uma vítima oferecida em sacrifício (ATWOOD, 2017b). Em várias passagens de seu relato, Offred se mostra consciente de sua invisibilidade como sujeito e da limitação de sua existência a fins procriativos:

Eu costumava pensar em meu corpo como um instrumento de prazer, ou um meio de transporte, ou um implemento para a realização de minha vontade. [...] Havia limites, mas meu corpo era, apesar disso, flexível, único, sólido, parte de mim.

Agora a carne se arruma de uma maneira diferente, sou uma nuvem congelada ao redor de um objeto central, com o formato de uma pera, que é duro e mais real do que eu e que incandesce vermelho dentro de seu invólucro translúcido. (ATWOOD, 2017a, p. 90)

Somos [as Aias] receptáculos, somente as entranhas de nossos corpos é que são consideradas importantes. O exterior pode se tornar duro e enrugado, pouco lhes importa, como a casca de uma noz. (ATWOOD, 2017a, p. 118)

Assim, Offred não é vista como pessoa em Gilead. Sua permanência na pirâmide social se dá única e exclusivamente pela sua utilidade. Sua capacidade de procriar é o que a diferencia das chamadas "unwomen" ("não-mulheres”), cujo destino, por serem pecadoras e inférteis, é o trabalho forçado nas Colônias, áreas distantes com alto nível de radiação e perspectiva de morte lenta e dolorosa. A esse respeito, é interessante notar o uso do prefixo de negação un- para demarcar aqueles cuja existência é anulada por não servirem aos propósitos de Gilead. Ele também está presente no termo "unbabies" ("nãobebês") para referir recém-nascidos que apresentam deformidades e são descartados por essa razão.

Além da negação do próprio nome, Offred tem sua liberdade de expressão cerceada. As Aias só podem se dirigir a outros membros da sociedade quando há permissão ou são demandadas a fazê-lo. Mesmo nesses contextos, sua fala é limitada a um protocolo padronizado de conversação. As passagens abaixo exemplificam a restrição da palavra imposta à protagonista: 
Não me chame de senhora, disse ela [a Esposa do Comandante] com irritação. Você não é uma Martha.

Não perguntei de que eu deveria chamá-la, porque podia ver que ela esperava que eu nunca tivesse a oportunidade de chamá-la de coisa nenhuma. [...].

Sim, senhora, respondi de novo, me esquecendo. Costumava haver bonecas, para garotinhas, que falavam se você puxasse um cordão na parte de trás; pensei que minha voz estava soando assim, uma voz monótona, uma voz de boneca. (ATWOOD, 2017a, p. 25-26)

- Bendido seja o fruto - diz ela [Aia que é companheira de compras de Offred] para mim, a expressão de cumprimento considerada correta.

- Que o Senhor possa abrir - respondo, a resposta também correta. (ATWOOD, 2017a, p. 29)

Consoante Foucault (2003, p. 36-7), um dos mecanismos que permitem o controle do discurso consiste justamente em determinar as condições de seu funcionamento, estabelecendo regras não acessíveis a todos. Opera-se, consequentemente, uma seleção dos sujeitos que falam, uma vez que aqueles que não se mostrarem qualificados são excluídos da ordem do discurso. Assim, considerando as convenções estabelecidas em Gilead, Offred ocupa um papel totalmente marginal nas práticas discursivas da sociedade em que vive.

Em verdade, a restrição do discurso não é uma exclusividade das Aias. Mesmo mulheres das classes mais altas não podem falar livremente. Como a narrativa de Offred revela, até alguém importante como Serena Joy, Esposa de seu Comandante e uma das vozes do discurso conservador que deu base ao golpe no período pré-regime, perde o direito à palavra: "Ela não faz mais discursos. Tornou-se incapaz de falar” (ATWOOD, 2017a, p. 58).

Os governantes de Gilead empregam diferentes estratégias para garantir a adesão a tal protocolo discursivo e, consequentemente, o silenciamento dos demais membros do corpo social. Além dos Olhos, espécie de polícia secreta que observa a população sem que esta saiba quando e onde, os próprios habitantes são delatores em potencial. Em vários momentos da narrativa, Offred mostra sua preocupação em relação ao que pode ou não dizer à sua companheira de compras com medo de ser denunciada. Assim, de maneira similar ao panóptico descrito por Foucault (2014), os membros de Gilead são 
permanentemente vigiados, como se houvesse um Deus onipresente que os observa o tempo todo, mesmo que seu olhar não seja perceptível.

Como fica evidente ao longo da narrativa de The Handmaid's Tale, em Gilead, os Comandantes são os grandes donos da palavra. São eles e as Tias - a estes subordinadas - os únicos que, por suas funções, estão autorizados a fazer uso da escrita. Consequentemente, somente membros dessas duas castas podem manusear as Sagradas Escrituras. Toda interpretação do texto bíblico fica, então, a cargo dos Comandantes, que tomam as decisões e governam Gilead. As Tias, por sua vez, constituem um elemento importante na manutenção da estrutura social do país. São elas as responsáveis por capacitar as Aias a desempenharem sua função. É no Centro Vermelho, sob a gestão das Tias, que as Aias:

aprendem a renunciar suas identidades prévias, a reconhecer seu papel e seus deveres, a entender que não possuem direitos, mas serão protegidas até certo ponto caso se ajustem, e a pensar tão pouco de si mesmas que aceitarão o destino que lhes foi atribuído e não se rebelarão ou fugirão. (ATWOOD, 2017b, tradução nossa)

Na realidade, como é esclarecido em The Testaments (2019) - sequência de The Handmaid's Tale traduzida no Brasil como Os Testamentos - as Tias são também responsáveis pela educação das meninas das famílias da elite, ensinando-as a se tornarem Esposas ou Tias (ATWOOD, 2019). Conforme sinaliza Foucault (2003, p. 44), o sistema educacional constitui uma importante ferramenta de controle social, uma vez que "é uma maneira política de manter ou de modificar a apropriação dos discursos, com os saberes e os poderes que trazem consigo". Não à toa, em The Testaments, é por meio de sua influência nesse sistema que Tia Lydia encontra meios para derrubar o regime.

Por fim, cabe destacar que, em Gilead, a Bíblia é vista como a única fonte de verdade, pautando toda dinâmica social. É no mito bíblico de Jacó, por exemplo, que os governantes encontram respaldo para o abuso das Aias:

Vendo, pois, Raquel que não dava filhos a Jacob, teve Raquel inveja da sua irmã, e disse a Jacob: Dá-me filhos, ou senão eu morro.

Então se acendeu a ira de Jacob contra Raquel e disse: Estou eu no lugar de Deus, que te impediu o fruto de teu ventre? 
E ela lhe disse: eis aqui a minha serva, Bilha; Entra nela para que tenha filhos sobre os meus joelhos e eu, assim, receba filhos por ela. (BÍBLIA, Gênesis, 30, 1-3 apud ATWOOD, 2017a, p. 5)

Com base em tal passagem, todos os meses, Offred, como qualquer Aia, é obrigada a participar da "Cerimônia" em seu período fértil. Durante o ritual, ela, à semelhança de Bilha, deve se deitar sobre os joelhos da Esposa de seu Comandante para ser penetrada por este. Caso seja agraciada com a concepção, o fruto de seu ventre não Ihe pertencerá: os pais da criança serão o Comandante e a sua Esposa.

Embora tratada como verdade universal, a Bíblia é manipulada de acordo com os anseios dos Comandantes. Assim, não apenas são selecionadas as passagens que convêm a seus propósitos, como o próprio discurso bíblico é alterado para atender aos fins desejados. Embora impotente diante disso, Offred se mostra consciente do procedimento:

Na hora do almoço eram as Beatitudes. [...] Elas [as Tias] punham para tocar uma gravação em disco, a voz era de um homem. Bem-aventurados os pobres de espírito, porque deles é o reino dos céus. [...] Bemaventurados os que se calam. Eu sabia que este último eles tinham inventado, sabia que estava errado, e que tinham excluído partes também, mas não havia nenhuma maneira de verificar. (ATWOOD, 2017a, p. 109)

Assim, a vontade de verdade, mascarada em verdade única e universal, conforme observado por Foucault (2003), torna o texto bíblico o único discurso válido na sociedade de Gilead. Como detentores da palavra, os Comandantes fazem uso das Sagradas Escrituras para ressignificar e moldar a realidade. Tanto é assim que Offred não sabe nem mesmo nomear o estupro como tal:

Minha saia vermelha é puxada para cima até minha cintura, mas não acima disso. Abaixo dela o Comandante está fodendo. O que ele está fodendo é a parte inferior de meu corpo. Não digo fazendo amor, porque não é o que ele está fazendo. Copular também seria inadequado porque teria como pressuposto duas pessoas e apenas uma está envolvida. Tampouco estupro descreve o ato: nada está acontecendo aqui que eu não tenha concordado formalmente em fazer. Não havia muita escolha, mas havia alguma, e isso foi o que escolhi. (ATWOOD, 2017a, p. 115) 
O momento apresentado na narrativa de The Handmaid's Tale é entendido por seus governantes como um período de transição. Todas as estratégias mencionadas visam não só vigiar e punir possíveis dissidentes como também condicionar seus habitantes. Em suas memórias sobre o Centro Vermelho, por exemplo, Offred recorda falas de Tia Lydia, nas quais esta prevê um tempo futuro em que as Aias não mais estranharão suas obrigações, pois Ihes parecerão costumeiras. Além disso, Esposas e Aias seriam amigas, pois ambas aceitariam seus papéis sociais.

Em sua narrativa, Offred já dá sinais dessa internalização do discurso imposto pelas classes dominantes. Por exemplo, ao se deparar com turistas estrangeiras que não seguem os protocolos sociais de Gilead, Offred se escandaliza com a maneira como se vestem, muito embora ela própria usasse roupas assim no período pré-regime:

Paro de andar. Ofglen para ao meu lado e sei que ela também não consegue tirar os olhos daquelas mulheres. Estamos fascinadas, mas ao mesmo tempo sentimos repulsa. Elas parecem despidas. Foi preciso tão pouco tempo para mudar nossas ideias a respeito de coisas como essa. (ATWOOD, 2017a, p. 40)

Embora os recursos empregados sejam distintos, como em Brave New World, as estratégias coercivas empregadas em Gilead visam a um processo de transformação social a partir do qual seus habitantes passem a aceitar e cumprir de bom grado os papéis que lhes foram designados. Na terminologia foucaultiana, são os chamados "corpos dóceis", corpos disciplinados que podem ser moldados e aperfeiçoados para serem úteis, corpos tão obedientes quanto produtivos (FOUCAULT, 2014).

Explicitados os mecanismos de controle utilizados em Gilead, a próxima seção deste artigo será dedicada à análise de como se configuram os atos de oposição ao regime, centrando-se especialmente na figura de Offred, como protagonista do romance, e no uso da linguagem como forma de resistência. 


\section{O jogo das palavras em THT}

Como a narrativa é toda apresentada da perspectiva de Offred que, por sua casta, tem um acesso bastante limitado aos acontecimentos à sua volta, não há como ter um quadro amplo sobre os atos de resistência em Gilead. O principal movimento nesse sentido registrado pela protagonista é o chamado "Mayday". Embora não haja muitas informações a seu respeito, uma vez que Offred toma conhecimento da organização em uma conversa com sua companheira de compras, trata-se de uma espécie de rede secreta que coleta informações e planeja ações contra o regime.

No âmbito individual, por sua vez, Offred, em várias passagens de seu relato, revela sua oposição à ideologia dominante no país e dá mostras de que sua aparente submissão é uma espécie de teatralização de si mesma a fim de garantir sua sobrevivência: "Espero. Eu me componho. Aquilo a que chamo de mim mesma é uma coisa que agora tenho que compor, como se compõe um discurso. O que tenho que apresentar é uma coisa feita, não algo nascido" (ATWOOD, 2017a, p. 82).

Dessa forma, apesar de aparentemente ceder à repressão, Offred o faz de forma consciente. Seu objetivo é manter-se viva e sobreviver ao autoritarismo. Sua submissão está restrita ao que é necessário para atingir esse fim. Suas ações, mais do que mostras de sujeição ao sistema, configuram atos de resistência. Tanto é assim que, não obstante as tentativas de limar sua subjetividade, Offred preserva, em segredo, sua identidade:

Meu nome não é Offred, tenho outro nome que ninguém usa porque é proibido. Digo a mim mesma que isso não tem importância, seu nome é como o número de seu telefone, útil apenas para os outros; mas o que digo a mim mesma está errado, tem importância sim. Mantenho o conhecimento desse nome como algo escondido, algum tesouro que voltarei para escavar e buscar, algum dia. Penso nesse nome como enterrado. Esse nome tem uma aura ao seu redor, como um amuleto, um encantamento qualquer que sobreviveu de um passado inimaginavelmente distante. (ATWOOD, 2017a, p. 103)

Seguindo esse princípio de sobrevivência, Offred revela, ao longo de sua narrativa, pequenos atos de transgressão, imperceptíveis aos olhos do sistema, mas que, para ela, têm um efeito gratificante, mantendo viva a sua individualidade. Pequenos gestos como 
balançar os quadris para provocar os olhares dos Guardiões ou furtar manteiga das refeições para hidratar sua pele dão ânimo à personagem.

No entanto, é por meio da linguagem que Offred realiza seu grande ato de resistência ao sistema. Apesar de toda repressão e vigilância a que está submetida, ela toma a palavra e se apresenta como alguém que constrói sua própria história. Embora não tenha como mudar os acontecimentos à sua volta, Offred entende que o ato de narrar instaura uma realidade e que, ao narrar, ela controla a realidade por meio da linguagem:

Gostaria de acreditar que isso é uma história que estou contando. Preciso acreditar nisso. Tenho que acreditar nisso. Aquelas que conseguem acreditar que essas histórias são apenas histórias têm chances melhores. Se for uma história que estou contando, então tenho controle sobre o final. Então haverá um final, para a história, e a vida real virá depois dele. Poderei recomeçar de onde interrompi.

Isso não é uma história que estou contando.

É também uma história que estou contando, em minha cabeça, à medida que avanço. (ATWOOD, 2017a, p. 52)

Como pontua Sisk (1997, p. 117), embora as classes dominantes de Gilead façam uso de uma série de mecanismos para controlar a história (history) como se fosse uma narrativa estática, Offred se mostra consciente de que ela narra uma história (story) com inúmeras variações possíveis. Assim, ao longo de seu relato, ela passeia por suas memórias, revisita e reelabora os acontecimentos, faz projeções sobre os outros e sobre si mesma, sempre atenta ao fato de que sua narrativa é uma reconstrução da realidade e de que, ao contrário da tentativa de monologização pretendida pelo regime, o ato de narrar não elimina a existência de outras versões.

Isso é uma reconstrução. Tudo, cada detalhe é uma reconstrução. É uma reconstrução agora, em minha cabeça, enquanto estou deitada estendida em minha cama de solteiro, ensaiando o que deveria ou não deveria ter dito, o que deveria ou não ter feito, como deveria ter feito meu jogo. Se algum dia sair daqui...

$[\ldots]$.

Quando eu sair daqui, se algum dia conseguir registrar isso, de qualquer modo, mesmo sob a forma de uma voz para outra, será uma reconstrução também, e um grau ainda mais distante. É impossível dizer 
alguma coisa exatamente da maneira como foi, porque o que você diz nunca pode ser exato, você sempre tem de deixar alguma coisa de fora, existem partes, lados, correntes contrárias e nuances demais; gestos demais, que poderiam significar isso ou aquilo, formas demais que nunca podem ser plenamente descritas, sabores demais, no ar ou na língua, semitonalidades, quase cores, demais. (ATWOOD, 2017a, p. 163)

Essa reconstrução da realidade ajuda a protagonista a manter a sanidade e a preservar sua individualidade dentro do sistema repressivo e castrador de Gilead. Além de encontrar em suas memórias uma possibilidade de fuga da realidade, Offred pode, por meio de sua narrativa, suavizar ou reinterpretar os fatos à sua volta, tornando-os mais suportáveis. Um exemplo disso é a romantização de sua primeira relação sexual com Nick. Offred é consciente de que está ali para engravidar e atender a uma demanda de Serena, que presume uma possível infertilidade do marido. No entanto, a primeira descrição de Offred sugere o encontro entre dois amantes envolvidos carnal e afetivamente. Ela admite ter criado essa cena e também outras a respeito de sua ligação com Nick, ciente de que, mais do que os fatos, importa como isso a afeta: "Não tenho certeza de como aconteceu; não exatamente. Tudo o que posso ter esperança de conseguir é uma reconstrução: a maneira como se sente o amor é sempre apenas uma aproximação" (ATWOOD, 2017a, p. 311).

Para além da possibilidade de narrar e construir sua própria história, a linguagem é também o que permite a Offred quebrar o isolamento que o sistema Ihe impõe. Como pondera Bakhtin (2009, p. 116-7), a palavra não constitui um simples produto da expressão individual, mas funciona como espécie de ponte entre o eu e o outro. Assim, ainda que no momento da enunciação este seja apenas uma projeção, Offred se dirige a um interlocutor e se constrói no diálogo com ele:

Mas continuo essa história triste e faminta e sórdida, esta história manca e mutilada, porque afinal quero que você a ouça, como ouvirei a sua também se algum dia tiver a chance, se encontrar você ou você escapar, no futuro ou no Céu ou na prisão ou na clandestinidade, em algum outro lugar. O que elas têm em comum é que não estão aqui. Ao contar a você qualquer coisa que seja, pelo menos estou acreditando em você, acredito que esteja presente, ao acreditar faço com que você exista. Pelo fato de estar lhe contando esta história determino a sua existência. Conto, portanto você existe. (ATWOOD, 2017a, p. 315-316) 
Além disso, a persistência da linguagem, apesar de todos os esforços para suprimila, é também o que possibilita a Offred se conectar, em um plano mais concreto, com seus semelhantes. Não obstante as restrições discursivas que lhes são impostas, Offred e as demais Aias aproveitam momentos de menor vigilância para interagir entre si. Sussurrando entre caminhadas de compras ou em meio às aglomerações dos eventos públicos, elas atravessam "a linha invisível” da proibição (ATWOOD, 2017a, p. 203) e compartilham não só informações, mas também percepções sobre o mundo.

A interação mais significativa de Offred, entretanto, se dá de forma silenciosa. Explorando os detalhes de seu quarto na casa do Comandante, ela se depara com uma frase oculta esculpida em seu armário: "Nolite te bastardes carborundorum" (ATWOOD, 2017a, p. 65). Embora, a princípio, desconheça o emissor e o significado das palavras, Offred se percebe como destinatária dessa mensagem que, subvertendo as regras do sistema, resiste e chega até ela:

Não sabia o que significava e nem sequer em que língua estava escrito. Pensei que talvez fosse latim, mas eu não sabia nada de latim. Apesar disso, era uma mensagem, e a mensagem era por escrito, proibida exatamente por esse fato, e não tinha sido descoberta. Exceto por mim, para quem era destinada. Era destinada a quem quer que viesse a seguir. (ATWOOD, 2017a, p. 66)

Essa frase se torna uma espécie de mantra para a protagonista, dando-lhe força para seguir em seu projeto de sobrevivência. Embora esteja fisicamente sozinha, Offred se percebe em comunhão com alguém que compartilha de seu sofrimento e isso fortalece sua determinação em resistir ao sistema que lhe oprime. Ao longo da narrativa, Offred tem a confirmação de que, como suspeitava, a autora da mensagem é a Aia que Ihe precedeu na casa. Mais do que isso, descobre que a frase remete a um jogo de poder do qual ela própria passa a fazer parte.

Offred é demandada a ter encontros secretos com o Comandante em seu escritório, algo que foge aos protocolos de conduta de Gilead, uma vez que as Aias são vistas apenas como meio para procriação e não como companhias para entretenimento. Quebrando em um primeiro momento a expectativa de um encontro sexual, o 
Comandante convida Offred a jogar Scrabble com ele. Traduzido para o português como “Mexe-mexe", trata-se de um jogo de palavras-cruzadas que exige a astúcia dos competidores para formar o maior número de palavras possível.

A partir disso, se inicia um jogo de poder e sedução que tem a linguagem como campo de batalha. Uma ou duas noites por semana, Offred visita o escritório do Comandante para as partidas de Scrabble. A protagonista descreve o local como um “oásis do que é proibido” (ATWOOD, 2017a, p. 166) e o próprio Comandante a incentiva a quebrar as regras, oferecendo-lhe revistas, livros, maquiagem. No entanto, não se trata de um ato de afeto ou de generosidade por parte de Fred. Mesmo que aparentemente esteja abrindo mão de parte de seu poder, ele ainda controla o desenrolar de todo o evento, até mesmo os resultados dos jogos.

Offred, por sua vez, tem consciência da natureza de sua relação com o Comandante, muito embora, em certos momentos, sua narrativa pareça suavizar os gestos do opressor. Ela sabe que o tratamento que recebe não reflete nenhum apego pessoal por sua figura, mas sim a satisfação dos caprichos do Comandante. Tanto é assim que, ao longo dos encontros, Offred descobre que não foi a primeira. A Aia que lhe antecedeu também frequentou o escritório do Comandante e foi lá que aprendeu a frase que deixou como legado a sua substituta: um arremedo de latim que significa "Não deixe que os bastardos esmaguem você" (ATWOOD, 2017a, p. 224).

Apesar disso, Offred não esconde a satisfação que a aventura proibida lhe proporciona. Embora seja uma peça substituível no jogo de Fred, os encontros secretos Ihe devolvem a sensação de ser uma pessoa e não apenas um objeto da casa, o que pode justificar a caracterização por vezes condescendente que faz do Comandante:

Mas, ainda assim, de maneira bastante estúpida, estou mais feliz do que estava antes. É alguma coisa para fazer, para começar. Alguma coisa para preencher o tempo, à noite, em vez de ficar sozinha no meu quarto. É alguma outra coisa em que pensar. Eu não amo o Comandante nem nada parecido com isso, mas ele é interessante para mim, ocupa espaço, é mais do que uma sombra...

E eu para ele. Para ele não sou mais apenas um corpo usável. Para ele não sou apenas um barco sem carga, um cálice sem nenhum vinho dentro, uma barriga - para ser grosseira - que não está de barriga. Para ele eu não sou meramente vazia. (ATWOOD, 2017a, p. 196) 
Offred é consciente de que deveria ter ódio do Comandante, uma vez que ele é diretamente responsável por tudo que sofre, no entanto, não é isso o que sente. Embora não saiba nomear o que é, ela percebe que não é amor, mas algo mais complexo do que isso (ATWOOD, 2017a, p. 72). Offred se sente atraída pela sensação de poder que o Comandante Ihe oferece. Mesmo entendendo o risco dos encontros e estando ciente de que Fred tem o controle da situação, ela vê ali uma oportunidade de exercer algum domínio sobre ele.

Como analisa Sisk (1997, p. 122-124), três diferentes jogos ocorrem simultaneamente durante esses encontros clandestinos. No plano mais superficial, há as disputas de Scrabble, em que a criatividade sobre a linguagem e a habilidade de formar palavras literalmente contam pontos. Para além do jogo de tabuleiro, Offred e o Comandante competem intelectual e afetivamente. Também aí a linguagem é objeto de disputa. Embora pareça não ter uma exata noção do que pretende fazer com a Aia, Fred é consciente de que, à medida que esta entra em maior contato com a linguagem através do Scrabble, das leituras, das conversas e até mesmo do ato de escrever, mais controle ele adquire sobre ela para garantir sua cooperação. Ele não quebra as regras por mero entretenimento, mas para mostrar o seu poder. Por sua vez, Offred escuta e observa atentamente o Comandante, estudando o que dizer ou como proceder para tirar o melhor proveito possível da situação.

Por fim, em um terceiro nível, as partidas de Scrabble servem como metáfora para o próprio jogo da leitura que se trava em The Handmaid's Tale. Assim como no jogo de tabuleiro, Offred oferece fragmentos soltos e desarranjados, cabendo ao leitor organizálos à sua maneira. Como pontua Sisk (1997, p. 121), a narrativa está repleta de problematizações ("undercuttings") que põem em suspeita aquilo que é dito. Offred não fala completamente da posição de vítima. Ela é articulada e, em vários momentos, tece comentários que questionam sua própria narração dos eventos.

Além disso, as “Notas Históricas" (no original, "Historical Notes”) que sucedem o relato criam uma espécie de reviravolta que força o leitor a rever e reinterpretar o que foi lido. Por meio delas, fica evidente que a primeira pessoa "eu" se apresenta sob controle 
de uma terceira pessoa "nós": os pesquisadores que encontram as fitas K7 deixadas por Offred. Por meio da palestra da personagem Pieixoto, acadêmico que estuda as gravações, revela-se que o texto até então apresentado é resultado do trabalho de transcrição dos estudiosos. Assim, além da possibilidade de eventuais incorreções na transposição do relato oral para a escrita, Pieixoto admite que a própria organização da narrativa não é confiável e se dá com base em suposições, uma vez que as fitas foram encontradas desordenadas no fundo de uma caixa sem qualquer numeração.

Apesar disso, nem as restrições estabelecidas pelo regime opressor de Gilead, nem a interferência dos acadêmicos são capazes de silenciar ou controlar Offred no registro de suas experiências. Não à toa, Sisk (1997, p. 123) a considera a grande "gatuna" de The Handmaid's Tale. Em várias passagens da narrativa, a protagonista revela seu desejo de roubar algo e o que ela efetivamente rouba não é nada menos do que a linguagem e, por meio dela, conhecimento e poder.

\section{Considerações finais}

Seguindo os pressupostos da narrativa distópica, Margaret Atwood opera em The Handmaid's Tale uma extrapolação pessimista do que poderia vir a acontecer, tendo em vista os movimentos sociais em emergência na época da escrita do livro. Como a autora já revelou em entrevistas, a barbárie apresentada na obra não é simples fruto de sua imaginação, mas uma compilação do que já aconteceu em diferentes momentos da humanidade. Assim, embora os eventos narrados por Offred beirem o inacreditável, a História mostra o quão verossímeis podem ser e a própria protagonista nos alerta para o fato de que nada muda instantaneamente: aquilo que parece impossível agora pode estar em processo sem nos darmos conta.

Ao revisitar suas memórias e reinterpretar os eventos à sua volta, Offred lança o seu discurso adiante. Como ela mesma afirma ao longo da narrativa, todo ato de narrar pressupõe um interlocutor, ainda que fisicamente não haja ninguém. No plano interno da obra, Offred conta sua história na esperança de que seu relato encontre a si própria, um “eu” futuro que sobreviverá ao regime repressor de Gilead e, ainda que isso não 
aconteça, a um “outro" que, embora desconhecido, testemunhará sua existência como indivíduo. Para Offred, "narrar" e "ser" se confundem, daí a importância da linguagem como forma de resistência.

Em um plano mais amplo, o relato de Offred se destina a nós, leitores, para que nosso futuro seja diferente do que narra. Em uma época de ampla circulação de discursos extremistas e ultraconservadores como a que vivemos, The Handmaid's Tale nos alerta sobre o risco escondido atrás de soluções e ideologias radicais. Como manifesta a própria Margaret Atwood (2017b), sua obra se oferece como uma "antiprevisão": ao retratar de forma tão precisa um futuro tão cruel, talvez ele não venha a se concretizar.

\section{Referências}

ABREU, Relines Rufino de. $\mathbf{O}$ (des)velar de ideologias em The Handmaid's Tale: vozes/discursos entrelaçados nas amarras do poder. 2012. Dissertação (Mestrado em Estudos Linguísticos e Estudos Literários) - Universidade Federal de Goiás, Viçosa, 2012.

ATWOOD, Margaret. 0 conto da aia. Rio de Janeiro: Rocco, $2017 a$.

ATWOOD, Margaret. Margaret Atwood on what 'The Handmaid's Tale' means in the age of Trump". The New York Times, New York, 10 mar. 2017b. Disponível em https://www.nytimes.com/2017/03/10/books/review/margaret-atwood-handmaids-taleage-of-trump.html. Acesso em: 24 fev. 2020.

ATWOOD, Margaret. Os testamentos. Rio de Janeiro: Rocco, 2019.

BAKHTIN, Mikhail. Marxismo e filosofia da linguagem. São Paulo: Hucitec, 2009.

FOUCAULT, Michel. A ordem do discurso. São Paulo: Loyola, 2003.

FOUCAULT, Michel. Vigiar e punir: nascimento da prisão. Petrópolis: Vozes, 2014.

HUXLEY, Aldous. Admirável mundo novo. São Paulo: Globo, 2009.

ORWELL, George. 1984. São Paulo: Companhia das Letras, 2009.

SISK, David W. Transformations of language in modern dystopias. London: Greenwood Press, 1997. 
TRUJILLO, María Paulina Moreno. El cuento de la criada, lós símbolos y las mujeres em la narración distópica. Escritos, Medellín: UPB, v. 24, n. 52, p. 185-211, jan./jun. de 2016. Disponível em: http://www.scielo.org.co/pdf/esupb/v24n52/v24n52a09.pdf. Acesso em 22 jan. 2020.

Recebido em: 19/05/2020

Aprovado em: 28/11/2020

Universidade do Estado de Santa Catarina - UDESC

Centro de Ciências Humanas e da Educação - FAED

PerCursos

Volume 21 - Número 47 - Ano 2020 revistapercursos@gmail.com 